\title{
Radiocarbon dating of groundwater from a PZ-2 piezometer located in the foreground of Wieliczka Salt Mine, Poland
}

\author{
Marek Duliński ${ }^{1 *}$, Zbigniew Gorczyca ${ }^{1}$, Michał Marzec ${ }^{1}$, Robert Czub ${ }^{1}$, \\ Krzysztof Brudnik² \\ ${ }^{1}$ AGH - University of Science and Technology, Faculty of Physics and Applied Computer Science, Mickiewicza 30, \\ 30-059 Kraków, Poland \\ ${ }^{2}$ Wieliczka Salt Mine, Park Kingi 1, 32-020 Wieliczka, Poland \\ *corresponding author, e-mail: marek.dulinski@fis.agh.edu.pl
}

\begin{abstract}
A comparison of two methods of radiocarbon age determination of groundwater is presented. The simplest Pearson model and the "user-defined" option of the NETPATH program were considered. Both methods were used to determine the age of water from a PZ-2 piezometer that is situated in the foreground of chamber Z-32 in Wieliczka Salt Mine. Results of these calculations clearly demonstrate that ${ }^{14} \mathrm{C}$ ages obtained by the Pearson model can be significantly overestimated in comparison with those determined by the NETPATH code. Without additional data, such as the stable isotope composition of the water, conclusions on the age of the groundwater based solely on the Pearson model may be highly inadequate.
\end{abstract}

Key words: groundwater age, Pearson model, NETPATH program

\section{Introduction}

A PZ-2 piezometer was bored out in order to monitor the W-VI-32 and W-VI-6 inflows that are located under the Z-32 and Z-28 chambers, respectively. The W-VI-32 inflow is considered to rank amongst the most dangerous in the salt mine at Wieliczka. Water from this inflow has received the status of therapeutic water used in balneotherapy (d'Obyrn \& Postawa, 2013, 2014; d'Obyrn \& Rajchel, 2014). Based on stable isotope composition, inflow W-VI-32 received water during the late 1970s that was recharged under colder climatic conditions than those prevailing at the present day (Witczak et al., 2016). Over time, the isotope composition gradually changed, reaching values that are indicative of inflow of modern water at the start of the $21^{\text {st }}$ century. However, in 2013 the isotopic composition of water in piezometer PZ-2 was practically the same as that in the early stages of W-VI-32 inflow, indicating recharge in a colder climate. Thus, the PZ-2 piezometer has proved to be of no use for monitoring groundwater on the outskirts of chambers Z-32 and Z-28. The filter of the PZ-2 piezometer is positioned within the lower Chodenice Sand layer. Probably, the supply of the Z-32 inflow occurs through the upper layer of this Chodenice Sand which contacts Quaternary deposits at the surface and is separated from the lower Chodenice Sand layer by impermeable formations. However, results of isotopic analyses of water from the PZ-2 piezometer are very instructive, especially considering the aspect of ${ }^{14} \mathrm{C}$ dating. 
The occurrence of the radioactive carbon isotope, ${ }^{14} \mathrm{C}$ or radiocarbon, was first recognised by Libby (1946). Under natural conditions, radiocarbon is produced in the transitional region between the stratosphere and troposphere about $12 \mathrm{~km}$ above the earth's surface through the nuclear reaction of neutrons with nitrogen nuclei. In turn, neutrons are produced in a reaction between high-energy cosmic protons and molecules of the atmosphere. Oxidation of radiocarbon leads to formation of ${ }^{14} \mathrm{CO}_{2}$ which mixes with the bulk of atmospheric $\mathrm{CO}_{2}$. Molecules of ${ }^{14} \mathrm{CO}_{2}$ enter into isotope exchange reactions with oceanic water and are assimilated by land plants. As a consequence, all living organisms, both plants and animals, contain ${ }^{14} \mathrm{C}$ concentrations equal to that of atmospheric $\mathrm{CO}_{2 \mathrm{~g}}$. Living land plants in the process of root respiration release significant amounts of $\mathrm{CO}_{2 \mathrm{~g}}$ into the soil, with ${ }^{14} \mathrm{C}$ activity typical of bulk atmosphere. Water infiltrating through the soil layer dissolves this $\mathrm{CO}_{2}$ and thus becomes aggressive with respect to carbonate minerals present in soil and/or in underlying rock formations. Dissolution of carbonates may occur under open or closed system conditions with respect to gaseous $\mathrm{CO}_{2 g}$ (Garrels, 1960). Under open system conditions gaseous $\mathrm{CO}_{2}$ fully controls the isotopic composition of the total dissolved inorganic carbon (TDIC). All dissolved carbon molecules (dissolved $\mathrm{CO}_{2 \mathrm{aq}}, \mathrm{HCO}_{3}{ }^{-}, \mathrm{CO}_{3}{ }^{2-}$, and carbonate complexes) have a carbon isotope composition $\delta^{13} \mathrm{C}$ that results from fractionation under given conditions between individual carbonate molecules and gaseous $\mathrm{CO}_{2 \mathrm{~g}}$ and activity of ${ }^{14} \mathrm{C}_{0}$ equal $100 \mathrm{pMC}$. Under closed system conditions water first dissolves gaseous $\mathrm{CO}_{2 \mathrm{~g}}$ and then, after the contact with gas is cut off, dissolution of carbonate rocks occurs. Consequently, the concentration of TDIC is lower than in solutions formed in open systems and its isotopic composition $\left(\delta^{13} \mathrm{C}_{\mathrm{TDIC}}{ }^{14} \mathrm{C}(0)\right)$ takes on intermediate values between the composition of gaseous and carbonate phases that take part in the formation of carbonate mineralisation of water. Independently of conditions during formation, the TDIC reservoir may be affected by isotope exchange processes with the rock matrix containing carbonate minerals present along the flow path of groundwater through the aquifer. It can also be modified by an admixture of carbon that originated from decomposition of organic matter $(\mathrm{OM})$ or methane oxidation, by admixture of geogenic $\mathrm{CO}_{2}$, exchange with pore water, precipitation and/or redissolution of carbonates. This means that radiocarbon dating of ground water is a complicated procedure that requires additional knowledge of possible physicochemical processes along the migration path of water.

\section{Radiocarbon dating}

In general, the outline of radiocarbon dating of waters can be illustrated in the form of a diagram (Fig. 1).

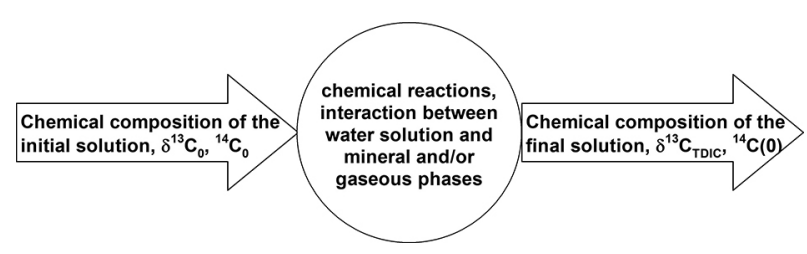

Fig. 1. Illustration of the ${ }^{14} \mathrm{C}$ method of determining the age of groundwater

The activity of ${ }^{14} \mathrm{C}_{0}$ in TDIC may be seriously reduced by geochemical processes that occur both in the unsaturated and saturated zone and lead to apparent dilution of the radiocarbon reservoir. Thus, the observed ${ }^{14} \mathrm{C}(0)$ activity in groundwater is a result of radioactive decay and geochemical reactions. Determination of the magnitude of ${ }^{14} \mathrm{C}_{0}$ dilution due to pure chemical evolution of water solution is an essential issue in correct radiocarbon dating of groundwater. Over the years, many models, including both chemical and isotope evolution of carbonate solutions, have been proposed to determine the modification of the initial activity of ${ }^{14} \mathrm{C}_{0}$. These were reviewed by Han \& Plummer (2016).

The simplest model of ${ }^{14} \mathrm{C}$ dating, including isotopic and chemical dilution correction, was formulated by Pearson (1965). It assumes that any change in ${ }^{14} \mathrm{C}$ will also be reflected in $\delta^{13} \mathrm{C}$. Mathematically it can be expressed by the equation:

$$
t=-8267 \ln \left(\frac{{ }^{14} \mathrm{C}(t)}{q^{14} \mathrm{C}(0)}\right)
$$

where ${ }^{14} \mathrm{C}(t)$ is the actually measured radiocarbon concentration in the TDIC reservoir of the water sample, ${ }^{14} \mathrm{C}(0)$ is the concentration of radiocarbon in the soil carbon dioxide in the aeration zone of the supply area of the investigated system, and $q$ is the correction factor that takes into account the changes in ${ }^{14} \mathrm{C}$ activity in TDIC due to dissolution of carbonate minerals, isotope exchange and other geochemical processes. Thus, the denominator $q^{14} \mathrm{C}(0)$ reflects the initial activity of ${ }^{14} \mathrm{C}$ corrected for dilution that results from various physicochemical reactions. Equation (1), in fact, represents a piston flow model and due to its simplicity is quite often used in proxy hydrological studies. In its simplest form 
the value of the correction factor $q$ can be calculated using the formula:

$$
q=\frac{\delta^{13} C_{\text {TDIC }}-\delta^{13} C_{\text {carb }}}{\delta^{13} C_{0}-\delta^{13} C_{\text {carb }}}
$$

where $\delta^{13} \mathrm{C}_{0}$ is the isotopic composition of soil carbon dioxide in the aeration zone, and $\delta^{13} \mathrm{C}_{\mathrm{TDIC}}$ the carbon isotope composition of dissolved carbonates. When carbonates of marine origin are dissolved the mean value of $\delta^{13} \mathrm{C}_{\text {carb }}=0 \%$ usually is assumed, leading to simplification of the formula (2). For many years, $\delta^{13} \mathrm{C}_{0}$ was assumed to be at the level of $-25 \%$, reflecting the average carbon isotope composition of C3 plants. However, investigations of carbon isotope composition of $\mathrm{CO}_{2}$ along soil profiles have proved that, due to kinetic fractionation during diffusion towards the soil surface and water table, the effective isotopic composition of soil $\mathrm{CO}_{2}$ in contact with infiltration water is equal to $-21 \div-23 \%$ o (e.g. Gorczyca, 2003).

The piston flow model usually leads to overestimation of calculated ages because it does not take into account the cation and isotope exchange processes between solution and rock matrix, both in the unsaturated and saturated zone. More precise determination of the radiocarbon age of water is possible using the NETPATH computer program (Plummer et al., 1991). In the "user-defined" mode it takes into account many parameters and reactions that occur between initial and final water along the flow path such as: calculation of mixing proportions of different waters, evaporation (or) dilution of waters, mineral mass transfer, reactions with gaseous phases, cation exchange and dissolution of organic matter. Depending on available isotope data the Rayleigh distillation formalism can be applied to each model, which satisfies defined constraints to predict carbon, sulphur and strontium isotopic composition of final water. A comprehensive assessment of the modification of the total dissolved carbon reservoir makes the calculated radiocarbon ages more reliable. However, for model calculations the chemical and isotopic composition of initial water should be known. Ideally, the chemical and isotopic parameters of water at input to the groundwater system, i.e., in the lower part of the unsaturated zone of an aquifer should be known. In the "phases" block of the computer program the mineralogical composition of rocks along the flow path of the water must be specified. In practice, both requirements in the given form are rarely met. Usually the parameters of input water are defined as mean values observed in the unsaturated zone in the expected recharge area. Assumptions about mineral phases are based on general knowledge of the geological structure of the rock reservoir and chemical composition of initial and final waters. Below, the approach described above will be applied.

\section{Construction of an input solution}

The shallow infiltration waters in the immediate vicinity of Wieliczka Salt Mine have been studied sporadically in the past. Unfortunately, even these limited data are not fully representative due to contamination with drilling fluids. However, the western part of GZWP-451 (Main Groundwater Reservoir) is the best-studied area closest to the salt mine. Both chemical and isotope investigations have been conducted in this region for many years. According to Kapusta (2012), two zones can be distinguished in this area:

- West A, represented by waters from wells located at Kokocice fort and the school at Rajsko, and from two wells (S-1 and S-2) in the city of Wieliczka;

- West B, including municipal wells S-10, S-11A and S-12 in the city of Wieliczka.

In all above-mentioned waters tritium was found, which indicates a short transition time of waters within the unsaturated zone, or just below it. For both zones, the representative mean water solutions were determined assuming mixing of individual waters in equal proportions. The results of calculations are presented in Table 1.

In Table 1 charge imbalance of water solution is defined as:

$$
B Q=\frac{\text { cat }- \text { an }}{\text { cat }+ \text { an }} 100
$$

where "cat" and "an" denote the sum of dissolved cations and anions expressed in equivalents, respectively. The calculated values of $B Q$ for West A, West B and PZ-2 waters are within the tolerance range $( \pm 5)$. For comparison, parameters of the theoretical solution $\mathrm{WZ}$, formed at $11^{\circ} \mathrm{C}$, at pressure of $\mathrm{CO}_{2}$ calculated as the average value for West $\mathrm{A}$ and $\mathrm{B}$ zones $(0.012 \mathrm{~atm})$ were also determined under open system conditions relative to $\mathrm{CO}_{2}$ gas. This solution was assumed to be in chemical and isotopic equilibrium with the gas phase, calcite and dolomite (hence the saturation indexes equal to 0.0 ; see Table 1).

Modelling of geochemical processes and calculation of radiocarbon age of water from the PZ-2 piezometer were carried out using the NETPATH 
Table 1. Chemical and isotope composition of water solutions in zones West A and West B, theoretically generated solution $\mathrm{WZ}$ and water from the PZ-2 piezometer

\begin{tabular}{|c|c|c|c|c|c|}
\hline \multicolumn{2}{|c|}{ Parameter } & West A & West B & WZ & PZ-2 \\
\hline Temperature & ${ }^{\circ} \mathrm{C}$ & 11.4 & 11.0 & 11.0 & 11.0 \\
\hline $\mathrm{pH}$ & - & 7.4 & 7.2 & 7.4 & 8.36 \\
\hline Eh & $\mathrm{mV}$ & 246 & 104 & - & 182 \\
\hline $\mathrm{Ca}^{2+}$ & $\mathrm{mg} / \mathrm{l}$ & 106.6 & 147.3 & 54.3 & 27.0 \\
\hline $\mathrm{Mg}^{2+}$ & $\mathrm{mg} / \mathrm{l}$ & 10.9 & 19.8 & 39.5 & 14.9 \\
\hline $\mathrm{Na}^{+}$ & $\mathrm{mg} / \mathrm{l}$ & 7.3 & 12.5 & - & 2423 \\
\hline $\mathrm{K}^{+}$ & $\mathrm{mg} / \mathrm{l}$ & 1.8 & 1.6 & - & 13.6 \\
\hline $\mathrm{Cl}^{-}$ & $\mathrm{mg} / \mathrm{l}$ & 23.7 & 22.8 & - & 2527 \\
\hline $\mathrm{SO}_{4}{ }^{2-}$ & $\mathrm{mg} / \mathrm{l}$ & 66.1 & 133.9 & - & 1066 \\
\hline $\mathrm{HCO}_{3}^{-}$ & $\mathrm{mg} / \mathrm{l}$ & 263.7 & 341.1 & 354.3 & 707 \\
\hline$\delta^{18} \mathrm{O}$ & \%o VSMOW & -10.1 & -9.8 & - & -10.6 \\
\hline$\delta^{2} \mathrm{H}$ & \% VSMOW & -71.0 & -69.3 & - & -75.3 \\
\hline$\delta^{13} \mathrm{C}$ & \%о VPDB & -14.2 & -13.3 & -13.5 & -13.2 \\
\hline${ }^{14} \mathrm{C}$ & pMC & $62.7^{*}$ & $44.4^{*}$ & $100^{* *}$ & 5.5 \\
\hline Charge imbalance & $\%$ & 1.74 & 3.18 & 0.0 & 1.57 \\
\hline $\mathrm{SI}_{\mathrm{C}}^{* * *}$ & - & 0.15 & 0.15 & 0.0 & 0.53 \\
\hline $\mathrm{SI}_{\mathrm{D}}^{* * *}$ & - & -0.53 & -0.43 & 0.0 & 0.96 \\
\hline $\mathrm{CO}_{2}$ & atm & 0.008 & 0.017 & 0.012 & 0.002 \\
\hline
\end{tabular}

* - values of ${ }^{14} \mathrm{C}(0)$ at the input to the saturation zone.

** - activity of ${ }^{14} \mathrm{C}_{0}$ of soil $\mathrm{CO}_{2}$ participating in formation of carbonate solution.

*** - saturation indexes with respect to calcite $\mathrm{SI}_{\mathrm{C}}$ and dolomite $\mathrm{SI}_{\mathrm{D}}$.

code with the following assumed parameters, phases and processes:

- the so-called "constraints", i.e., elements and balances: $\mathrm{C}, \mathrm{Ca}, \mathrm{Mg}, \mathrm{Na}, \mathrm{K}, \mathrm{S}, \mathrm{Cl}, \delta^{13} \mathrm{C}$;

- mineral and gas phases: $\mathrm{CO}_{2}$ gas, $\mathrm{CH}_{2} \mathrm{O}$ (organic matter, OM), calcite dolomite, halite, gypsum, plagioclase- $(\mathrm{Ca}, \mathrm{Na})$;

- cation exchange processes: $\mathrm{Ca} / \mathrm{Na}$ and $\mathrm{Mg} / \mathrm{Na}$. Consideration of carbon isotope exchange between solid carbonates and dissolved carbon was not necessary. Due to the observed differences in mineralisation between the initial solutions and the solution from the PZ-2 well, the dissolution of halite, gypsum, organic matter and plagioclase was forced in each model. Results of calculations are summarised in Table 2 . In that table only those models are presented for which the calculated value of $\delta^{13} \mathrm{C}$ was in agreement with the measured in TDIC from piezometer PZ-2, i.e., $-13.2 \%$.

Table 2. Results of model calculations of radiocarbon age using the NETPATH program

\begin{tabular}{|c|c|c|c|c|c|c|c|}
\hline \multirow{2}{*}{$\begin{array}{l}\text { Initial solution } \\
\text { Model No. }\end{array}$} & \multicolumn{3}{|c|}{ West A } & \multicolumn{2}{|c|}{ West B } & \multicolumn{2}{|c|}{ WZ } \\
\hline & 1 & 2 & 3 & 1 & 2 & 1 & 2 \\
\hline \multicolumn{8}{|l|}{ Mineral phase } \\
\hline Halite $(+)$ & 71.10 & 71.10 & 71.10 & 71.12 & 71.12 & 71.76 & 71.76 \\
\hline Gypsum (+) & 10.48 & 10.48 & 10.48 & 9.78 & 9.78 & 11.17 & 11.17 \\
\hline $\mathrm{CH}_{2} \mathrm{O}(+)$ & 3.37 & 3.37 & 3.37 & 2.63 & 2.63 & 2.63 & 2.63 \\
\hline Plagioclase (+) & 2.44 & 2.44 & 2.44 & 2.69 & 2.69 & 2.67 & 2.67 \\
\hline Calcite & 3.03 & 3.37 & - & 2.40 & - & 2.47 & - \\
\hline Dolomite & 0.17 & - & 1.68 & - & 1.20 & - & 1.24 \\
\hline $\mathrm{Ca} / \mathrm{Na}$ exchange & 16.59 & 16.76 & 15.08 & 16.19 & 15.00 & 15.34 & 14.10 \\
\hline $\mathrm{Mg} / \mathrm{Na}$ exchange & - & -0.17 & 1.52 & 0.20 & 1.40 & 1.01 & 2.25 \\
\hline${ }^{14} \mathrm{C}(\mathrm{pMC})$ & 25.90 & 25.90 & 25.90 & 25.00 & 25.00 & 55.70 & 55.70 \\
\hline${ }^{14} \mathrm{C}$ age (years) & 12800 & 12800 & 12800 & 12500 & 12500 & 19100 & 19100 \\
\hline
\end{tabular}

Note: the amounts of transferred minerals between the solid and liquid phases are expressed in mmol/L; the sign (+) means "forced phase", i.e. the phases whose presence and dissolution were forced in each of the models; positive values mean the dissolved quantity of a given phase, negative - removed from the solution. 


\section{Results of ${ }^{14} \mathrm{C}$ dating}

Using the piston flow Pearson model, assuming the mean value $\delta^{13} C_{0}$ of soil carbon dioxide to be equal to $-22 \%$ and initial ${ }^{14} \mathrm{C}_{0}$ activity at the level of $100 \mathrm{pMC}$, the radiocarbon age of water from the PZ-2 piezometer equals 19,800 years. A similar age $(19,100$ years) has been obtained by model calculations with the NETPATH code, starting from the theoretical solution WZ. Both age determinations remain in good agreement and this fact requires some comment.

Both the Pearson model and calculations using the NETPATH program with the WZ initial solution assume that ${ }^{14} \mathrm{C}_{0}$ activity of dissolved carbonates in water entering the saturation zone is equal to 100 pMC. Similarly, in the case of closed systems, it is assumed that the infiltrating water is initially saturated with gaseous $\mathrm{CO}_{2}$ originating from root respiration and then, after cutting off gas supply, carbonate minerals are dissolved. These are two extreme, theoretical scenarios. In practice, indirect variants are realised. Data from the GZWP451 aquifer clearly indicate successive closing of the system as water flows through the unsaturated zone (Duliński et al., 2013). Hence, the activities of ${ }^{14} \mathrm{C}$ in waters containing significant amounts of tritium (and therefore of relatively young age, i.e., several dozens of years old) are considerably smaller than 100 pMC. In the Pearson model the initial activity of ${ }^{14} \mathrm{C}(0)$, after correction for dissolution (Eq. 2 ), is equal to $60 \mathrm{pMC}$, whereas the analogous value calculated by the NETPATH program is only 25-26 pMC. Using parameters of the initial solutions determined for zones West A and B, three and two very coherent models are obtained, respectively. The calculated ${ }^{14} \mathrm{C}$ ages for these models are closely similar and equal 12,500-12,800 years.

Results of calculations starting with initial solution formed under a closed system conditions relative to gaseous $\mathrm{CO}_{2}$ are omitted, because they lead to absurd chemical models that generate negative ages. By the way, the incorrectness of such an approach is indicated by too low $\delta^{13} \mathrm{C}$ values.

It is difficult to assume that the recharge zone of the PZ-2 well differs drastically in terms of hydrochemical and geological parameters from conditions prevailing in zones West A and West B. This implies that the age of water from the PZ-2 piezometer is close to 12,500 , rather than 19,000 , years. This younger date is also confirmed by the stable isotope composition of water.

The isotopic composition of water from the PZ-2 piezometer is lower than the average composition of Holocene infiltration in the Kraków area. This is proof of the presence of a component recharged under climatic conditions that are colder than those prevailing currently. The age of the water, about 12,500 years, places it at the boundary between the Younger Dryas and Preboreal, i.e., within the period of significant and rapid climate change. Probably, this water represents a mixture of melting water being the remains of the last glaciation (with a more negative isotopic composition) and early Holocene waters. The contribution of glacial water is not very high. This is evident from the isotopic composition of water in the M3 borehole at Kraków-Mateczny: $\delta^{18} \mathrm{O}=-12.8 \%$, $\delta^{2} \mathrm{H}=-85 \%$ (Zuber \& Rajchel, 2007).

\section{Conclusions}

In the present paper, a comparative analysis of two radiocarbon dating methods of groundwater from PZ-2 piezometer is made: the Pearson model and the "user-defined" option of the NETPATH program. The simpler Pearson model considers dilution of the dissolved carbon reservoir by carbonate minerals only. In the NETPATH code, numerous processes can be modelled, which leads to more precise determination of geochemically corrected initial ${ }^{14} \mathrm{C}(0)$ activity as the starting point for age determination. Using physicochemical parameters of water from the PZ-2 piezometer in the vicinity of Wieliczka Salt Mine, it is shown that the very simple Pearson model can lead to significantly overestimated ${ }^{14} \mathrm{C}$ ages. In the case of analysed water, the aging effect is about 7,000 years. This may be behind erroneous conclusions on the origin of water in those cases where other data are unavailable. The age of the water from the PZ-2 piezometer could be verified by using its oxygen and hydrogen isotopic composition. However, without such additional data, application of the Pearson model, albeit very simple, can result in markedly erroneous conclusions.

\section{Acknowledgements}

In part, the present work was supported by the Ministry of Science and Higher Education, project number 16.16.220.842 B02.

\section{References}

d'Obyrn, K. \& Postawa, A., 2013. Selected hydrochemical ratios of waters from inflows at the level VI in "Wieliczka" salt mine. Geology, Geophysics and Environment 39, 163-174. 
d'Obyrn, K. \& Postawa, A., 2014. Assessment of the qualitative and quantitative stability of "Wieliczka" Salt Mine (Poland) brines and of their possible use for medical purposes. Geological Quarterly 58, 459-464.

d'Obyrn, K. \& Rajchel, L., 2014. Balneologiczne walory Kopalni Soli „Wieliczka” [Balneological values of the Wieliczka Salt Mine]. Acta Balneologica 61, 220-223.

Duliński, M., Rozanski, K., Kuc, T., Gorczyca, Z., Kania, J. \& Kapusta, M., 2013. Evolution of radiocarbon in a sandy aquifer cross large temporal and spatial scales: case study from southern Poland. Radiocarbon 55, 905-919.

Garrels, R.M., 1960. Mineral Equilibria at Low Temperature and Pressure. Harper \& Brothers Publishers, New York, $254 \mathrm{pp}$.

Gorczyca, Z., 2003. Badania zmienności składu izotopowego strumienia glebowego dwutlenku węgla do atmosfery na obszarze Polski południowej [Variability of the isotope composition of the soil $\mathrm{CO}_{2}$ flux to the atmosphere in the Southern Poland]. University of Science and Technology, Kraków, 169 pp.

Han, L.F. \& Plummer, L.N., 2016. A review of single-sample-based models and other approaches for radiocarbon dating of dissolved inorganic carbon in groundwater. Earth-Science Reviews 152, 119-142.

Kapusta, M., 2012. Datowanie wód podziemnych z wykorzystaniem radiowęgla - zagadnienia metodyczne i zastosowanie [Dating groundwater using radiocarbon - methodological issues and application]. University of Science and Technology, Kraków, 88 pp.
Libby, W.F., 1946. Atmospheric helium three and radiocarbon from cosmic radiation. Physical Review 69, 671-672.

Pearson, F.J.Jr., 1965. Use of C13/C12 ratios to correct radiocarbon ages of materials initially diluted by limestone. Proceedings of the $6^{\text {th }}$ International Conference on Radiocarbon and Tritium Dating, Pullman, USA, 357366.

Plummer, L.N., Prestemon, E.C. \& Parkhurst, D.L., 1991. An interactive code (NETPATH) for modeling NET geochemical reactions along a flow PATH. Water-Resources Investigations Report 91-4078, U.S. Geological Survey, Reston, $130 \mathrm{pp}$.

Witczak, S., d'Obyrn, K., Duliński, M. \& Rajchel, L., 2016. Warunki zasilania wód leczniczych w Kopalni Soli Wieliczka [Conditions of medicinal water supply in the Wieliczka Salt Mine]. Biuletyn Państwowego Instytutu Geologicznego 466, 313-322.

Zuber, A. \& Rajchel, L., 2007. Geneza wód mineralnych Matecznego, Kraków [Origin of mineral waters in Kraków-Mateczny]. [In:] A. Szczepański, E. Kmiecik \& A. Żurek (Eds): Wspótczesne problemy hydrogeologii XIII [Contemporary Problems of Hydrogeology XIII]. University of Science and Technology, Kraków, 995-1002.

Manuscript received: 25 March 2019

Revision accepted: 26 July 2019 